\title{
Sperm Surface Protein Sp17
}

National Cancer Institute

\section{Source}

National Cancer Institute. Sperm Surface Protein Sp17. NCI Thesaurus. Code C142992.

Sperm surface protein Sp17 (151 aa, $17 \mathrm{kDa}$ ) is encoded by the human SPA17 gene.

This protein plays a role in the binding of spermatozoa to the carbohydrates in the zona pellucida. 